NORBERT SLENZOK

\title{
Problem demokracji totalitarnej w filozofii politycznej libertarianizmu
}

\section{Wprowadzenie}

Stosunki pomiędzy demokracją a wolnością - czy też między demokratyzmem a liberalizmem - należą do centralnych tematów współczesnej filozofii politycznej i teorii polityki ${ }^{1}$. Wypowiadających się na ten temat autorów można podzielić w pewnym uproszczeniu na dwie grupy. W pierwszej z nich znajdowaliby się ci, którzy — jak Jürgen Habermas, John Rawls czy Robert Dahl, by wymienić tych najbardziej rozpoznawalnych — stoją na stanowisku głoszącym możliwość koherentnej syntezy wartości demokratycznych i liberalnych, a nawet istnienie koniecznych związków między nimi ${ }^{2}$. Na drugim biegunie pozycjonują się myśliciele i badacze eksponujący antywolnościowe czy zgoła totalitarne tendencje ustrojów demokratycznych. Wypada tu wymienić konserwatywnych liberałów: Erika von Kuehnelt-Leddihna oraz Friedricha von Hayeka. W swoich pracach obaj podkreślają, że demokracja i liberalizm to koncepcje należące do dwu różnych porządków. O ile bowiem w świetle ich rozpoznań demokracja byłaby jedną z koncepcji legitymizacji władzy, o tyle przedmiot zainteresowania liberalizmu stanowiłyby zakres i ograniczenia władzy. Innymi słowy, demokracja to w ich oczach odpowiedź na pytanie o źródło władzy, którym według demokratów ma być wola suwerennego ludu. Tymczasem liberalizm dostarcza rozwiązania innego zagadnienia: jak daleko ma sięgać władza państwa - na co odpowiadają

${ }^{1}$ G. Sartori, Teoria demokracji, przeł. P. Amsterdamski, D. Grindberg, Warszawa 1998, passim; J. Bartyzel, Śmiertelny bóg Demos. Pięć wyktadów o demokracji i jej krytykach, Warszawa 2009, s. 73-96.

2 Zob. R. Dahl, Demokracja i jej krytycy, przeł. S. Amsterdamski, Warszawa 2012; J. Habermas, Teoria działania komunikacyjnego, przeł. A.M. Kaniowski, Warszawa 2015; J. Rawls, Liberalizm polityczny, przeł. A. Romaniuk, Warszawa 2012. 
liberałowie, że winna ona być w ten czy inny sposób ograniczona celem zagwarantowania jednostkowych praw i wolności ${ }^{3}$. Dziedziny przedmiotowe liberalizmu i demokracji są zatem rozłączne, wobec czego nie można wykluczyć, że wola ludu stanie się zagrożeniem dla wolności dokładnie tak samo, jak wola tyrana. Co więcej, konstytutywna cecha ustroju demokratycznego — prymat większości nad mniejszością - skutkuje ustawicznym zagrożeniem wolności, niesionym przez rządy demokratyczne ${ }^{4}$.

Warto odnotować, że teza o nieredukowalnym napięciu pomiędzy demokracją a wolnością podnoszona jest nie tylko w sferze liberalnej myśli politycznej. Wśród filozofów społecznych lewicy o totalitarnym charakterze demokracji wiele pisał Herbert Marcuse, aczkolwiek — rzecz oczywista - jako reprezentant neomarksistowskiej szkoły frankfurckiej operował on zupełnie odmienną argumentacją niż Hayek czy Kuehnelt-Leddihn, wiążąc totalitaryzm z wszechobecnością kapitalistycznych, merkantylnych stosunków oraz zdolnością demokratycznego kapitalizmu do absorpcji opozycji antysystemowej w ramach pluralistycznego reżimu politycznego (tę ostatnią cechę określił Marcuse sławnym terminem „tolerancja represywna") 5 .

Pojęcie demokracji totalitarnej weszło natomiast do obiegu w latach 50. XX wieku za sprawą izraelskiego historyka idei Jacoba L. Talmona. Rozróżniał on dwa typy demokracji: totalitarną i liberalną. Podkreślał jednak zarazem, że nie jest tak, iżby za rozróżnieniem tym stał odmienny — odpowiednio wrogi i aprobatywny - stosunek do wolności. Oba rodzaje demokracji charakteryzuje raczej w ujęciu Talmona odmienne rozumienie tej kategorii. Podczas gdy demokracja liberalna traktuje wolność jako atrybut chronionej przed zewnętrznym przymusem jednostki, demokracja totalitarna przypisuje ją homogenicznemu kolektywowi kierującemu się jakąś odmianą roussoistowskiej woli powszechnej. Druga różnica między nimi jest zaś natury epistemologiczno-teleologicznej:

Podejście liberalne zakłada, że polityka to metoda prób i błędów; traktuje ono systemy polityczne jako pragmatyczne wynalazki ludzkiej pomysłowości i spontaniczności. Dostrzega ponadto różnorodność poziomów jednostkowych i zbiorowych dążeń pozostających całkowicie poza sferą polityki. Z drugiej strony, szkoła demokracji totalitarnej zakłada istnienie w polityce jednej, wyłącznej prawdy. Można ją nazwać mesjanizmem politycznym w tym znaczeniu, że postuluje ona ustalony z góry, harmonijny i doskonały układ spraw [...] Każdej ludzkiej

3 Zob. E. von Kuehnelt-Leddihn, Demokracja - opium dla ludu, przeł. M. Gawlik, Warszawa 2012, s. 13-20; F.A. Hayek, Konstytucja wolności, przeł. J. Stawiński, Warszawa 2006, s. 112-116.

${ }^{4}$ Wątek ten był szczególnie mocno eksponowany przez Kuehnelt-Leddihna - monarchistę i zaciekłego wroga demokracji. E. von Kuehnelt-Leddihn, op. cit., s. 31-35.

${ }^{5}$ H. Marcuse, Człowiek jednowymiarowy: badania nad ideologia rozwiniętego społeczeństwa przemysłowego, przeł. S. Konopacki, Warszawa 1991. Na temat pojęcia tolerancji represywnej zob. idem, Repressive Tolerance, [w:] idem, R.P. Wolff, B. Moore, A Critique of Pure Tolerance, Boston 1965, s. 81-117. 
myśli i każdemu działaniu przypisuje znaczenie społeczne i z tego tytułu wciąga je w orbitę działań politycznych — wywodził Talmon ${ }^{6}$.

Podsumowując, możemy w koncepcji Talmona wyróżnić trzy substancjalne składniki totalitarnej demokracji: kolektywizm (antyindywidualizm), teleologiczny monizm oparty na hegemonicznej ideologii oraz zniesienie granicy pomiędzy sferą publiczną a prywatną. Historycznie ideał taki miał wywodzić się z radykalnej myśli francuskiego oświecenia, obecnej w pismach Jana Jakuba Rousseau, Etienne'a-Gabriela Morelly'ego czy Gabriela Bonnota Mably, a kulminującej w politycznej działalności jakobinów i babuwistów ${ }^{7}$.

Celem niniejszego artykułu jest analiza i merytoryczna ocena wizji demokracji totalitarnej, jaką możemy odnaleźć w filozofii politycznej libertarianizmu. Libertarianizm to stosunkowo nowy nurt filozoficzno-polityczny, nawiązujący do tradycji klasycznego liberalizmu i indywidualistycznego anarchizmu, za którego najważniejszych przedstawicieli należy uznać Murraya N. Rothbarda i Hansa-Hermanna Hoppego. W ślad za Dariuszem Jurusiem definiujemy libertarianizm jako stanowisko, którego jądro stanowi uznanie absolutnego statusu prawa własności prywatnej, utożsamianego przez libertarian z wolnością ${ }^{8}$. Ma ono w myśli libertariańskiej dwojaki charakter. Odnosi się w pierwszej kolejności do samej osoby (lub też, jak sugeruje Hoppe, ciała) człowieka - jest to prawo auto-własności bądź też samoposiadania (ang. self-ownership). Dalej, absolutne prawo własności rozciąga się na sprawiedliwie zawłaszczone materialne przedmioty zewnętrzne. Do definicji libertarianizmu należy więc, jak wskazuje Stephan Kinsella, specyficzna koncepcja legitymowalnego zawłaszczania zewnętrznych dóbr ${ }^{9}$. Dochodzi do niego — jak wylicza Hoppe - na trzy i tylko trzy możliwe sposoby: a) wskutek pierwotnego zawłaszczenia wolnego zasobu; b) poprzez wyprodukowanie nieistniejącego wcześniej dobra; c) w drodze dobrowolnego transferu ${ }^{10}$. Imperatyw nakazujący respektowanie tak scharakteryzowanych praw własności określany jest natomiast mianem zasady nieagresji (ang. non-aggression princple) $)^{11}$.

Polityczną implikację tych założeń etycznych stanowi — jak pisze Kinsella — rynkowy anarchizm ${ }^{12}$. Pogląd ten, nazywany również przez adherentów libertarianizmu anarchokapitalizmem, społeczeństwem prawa prywatnego bądź ładem naturalnym, oznacza postulat likwidacji państwa poprzez prywatyzację wszelkich

6 J.L. Talmon, Źródła demokracji totalitarnej, przeł. A. Ehlrich, Kraków 2015, s. 9-10.

7 Ibidem, s. 40 n.

${ }^{8}$ D. Juruś, W poszukiwaniu podstaw libertarianizmu. W perspektywie Rothbardowskiej koncepcji własności, Kraków 2012, s. 10.

${ }^{9}$ S. Kinsella, What libertarianism is, [w:] Property, Freedom, and Society. Essays in Honour of Hans-Hermann Hoppe, red. J.G. Hulsmann, S. Kinsella, Aurburn 2009, s. 181.

${ }^{10}$ H.-H. Hoppe, Krótka historia czlowieka, przeł. Ł. Dominiak, Warszawa 2014, s. 99.

11 Zob. np. M.N. Rothbard, O nowa wolność. Manifest libertariański, przeł. W. Falkowski, Warszawa 2007, s. 45.

${ }^{12}$ S. Kinsella, op. cit., s. 196. 
jego społecznie niezbędnych funkcji, łącznie z prawodawstwem oraz zewnętrzną i wewnętrzną ochroną. Ów radykalny antyetatyzm ugruntowany jest na podłożu zarówno etycznym, jak i ekonomicznym. W tym pierwszym aspekcie państwo znajdowane jest jako twór immanentnie niemoralny, z istoty ufundowany na systematycznym zadawaniu gwałtu prawom własności poprzez sprawowanie terytorialnego monopolu przemocy i opodatkowania (wprost określanego w libertariańskich publikacjach jako kradzież). Z kolei w wymiarze ekonomicznym libertarianie postrzegają państwo jako z konieczności nieefektywne, co wynikać ma między innymi z jego monopolistycznej natury.

Agencja ochrony opłacana z podatków jest antynomią, ponieważ protektor, który konfiskuje własność protegowanych, będzie nieuchronnie podwyższał podatki i zmniejszał ochronę przekonuje Hoppe ${ }^{13}$.

\section{Rothbard zaś dowodzi:}

Państwo jest zatem przymusową organizacją przestępczą, która żyje z ustanowionego przez siebie systemu podatkowo-rabunkowego $[\ldots]^{14}$. Jeśli przyjrzymy się państwu takiemu, jakie jest, odartemu z jego pozornego majestatu, to zauważymy, że pozwala mu się, wręcz zachęca się je, do popełniania czynów, które nawet w opinii nielibertarian stanowią karalne przestępstwa. Państwo nagminnie dopuszcza się masowej zbrodni, którą nazywa wojną, a innym razem thumieniem działań wywrotowych; państwo angażuje się w proceder niewolnictwa, zwanego poborem; państwo istnieje i utrzymuje się dzięki praktyce przymusowego złodziejstwa, które nazywa „opodatkowaniem”. [...] Wojna jest masowym morderstwem, pobór jest niewolnictwem, a podatki - grabieżą ${ }^{15}$.

Ponieważ zatem zło tkwi według libertarian w samej naturze państwa, jego nieprawości niepodobna usunąć w jakiejkolwiek formie ustrojowej; państwo zawsze i wszędzie depcze ludzką wolność. Zagadnieniem podejmowanym przez nas w tym artykule jest pytanie, czy skoro — z libertariańskiego punktu widzenia defekty państwa nie mogą zostać zlikwidowane inaczej niż w drodze likwidacji samego państwa, istnieje możliwość, by przynajmniej je ograniczyć. W naszym rozumieniu, w odniesieniu do ustroju demokratycznego pytanie to jest tożsame z pytaniem o możliwość istnienia totalitarnej demokracji. Tę ostatnią definiujemy tu bowiem szerzej niż Talmon, nazywając tak stan nieograniczonej władzy demokratycznego państwa nad jednostką, co oznacza, że spośród atrybutów wymienianych przez izraelskiego badacza za konstytutywne dla totalitarnej demokracji — i totalitaryzmu w ogóle - uznajemy zniesienie rozróżnienia między sferą publiczną i prywatną (resp. niepodlegającą ingerencji ze strony państwa). Podejście takie uzasadniamy następująco: po pierwsze, dążenie do całkowitego podporządkowania człowieka państwu stanowi wspólny komponent kanonicznych

13 H.-H. Hoppe, Demokracja - bóg, który zawiódt. Ekonomia i polityka demokracji, monarchii i ładu naturalnego, przeł. W. Falkowski, J. Jabłecki, Warszawa 2006, s. 300.

14 M.N. Rothbard, Etyka wolności, przeł. J. Wozinski, Warszawa 2010, s. 281.

15 M.N. Rothbard, O nowa wolność..., s. 46-47. 
definicji totalitaryzmu, takich jak te pochodzące od Carla Friedricha i Zbigniewa Brzezińskiego oraz Hannah Arendt, a ponadto odzwierciedla etymologię terminu „totalitaryzm” (łac. totalis - cały) ${ }^{16}$. Po drugie, libertariańska konceptualizacja totalitarnej demokracji jest przeciwstawna Talmonowskiej. W istocie, jak pokażemy, libertarianie wskazują, że totalitarna - tj. całościowa, nieograniczona władza przysługuje każdemu państwu demokratycznemu, także demokracjom liberalnym.

W toku dalszego wywodu pragniemy wykazać słuszność dwóch tez: 1) Choć czołowi autorzy libertariańscy nie posługują się w swoich pismach terminem „demokracja totalitarna”, kategoria ta, zdefiniowana tak jak powyżej, jest obecna w ich myśli. 2) Libertarianie mylą się co do totalitarnego w istocie charakteru demokracji. Nawet na gruncie libertariańskich pryncypiów etycznych można wskazać na znaczące ograniczenia, jakim podlega proceder naruszania praw podmiotowych przez demokratyczną władzę

\section{Totalitarna demokracja?}

\section{1) Demokracja a przymusowość państwa}

Nim przejdziemy do rozważań dotyczących demokracji totalitarnej, należy poświęcić kilka słów temu, dlaczego libertarianie nie podzielają wyrastającego z teorii umowy społecznej przekonania, jakoby państwo demokratyczne dzierżyło swoją władzę za zgodą rządzonych, tj. było de facto dobrowolnym stowarzyszeniem $^{17}$. Prowadzona przez Rothbarda, Hoppego i innych libertarian krytyka tego podejścia zasadza się na rygorystycznie konsekwentnym zastosowaniu zasad społecznego indywidualizmu. Świadomość i wola należą w ich optyce wyłącznie do jednostek, nigdy natomiast do kolektywów, toteż ideologia rządu - według znanej formuły Abrahama Lincolna — „ludu, przez lud i dla ludu” nie może uchodzić za nic innego, jak tylko niebezpieczny przesąd ${ }^{18}$. Rothbard komentuje go dobitnie:

„My” nie jesteśmy rządem, a rząd to nie „my”. [...] Rozumując w ten sposób, musimy dojść do wniosku, że Żydzi [niemieccy — przyp. N.S.] zamordowani przez władze nazistowskie nie zostali zamordowani, tylko „popełnili samobójstwo" ${ }^{19}$.

16 Z. Brzeziński, C. Friedrich, Totalitarian Dictatorship and Autocracy, New York 1966, s. 4, 21; H. Arendt, Korzenie totalitaryzmu, przeł. D. Grindberg, M. Szawiel, t. 1, Warszawa 1993, s. 494. Podobnie piszą na ten temat inni badacze. Zob. np. A. Heywood, Ideologie polityczne. Wprowadzenie, przeł. M. Habura et al.,Warszawa 2007, s. 234.

17 Na temat teorii umowy społecznej i jej libertariańskiej krytyki zob. szczególnie M. Huemer, The Problem of Political Authority. An Examination of the Right to Coerse and the Duty to Obey, New York 2013, s. 20-58.

18 J. Bartyzel, op. cit., s. 9.

19 M.N. Rothbard, O nowa wolność..., s. 76. 
Następnie dodaje:

Zbrodnia jest zbrodnią, agresja jest agresją, bez względu na to, jak wielu obywateli godzi się na takie praktyki. W pojęciu większości nie ma nic świętego. Tłum dokonujący samosądu stanowi przecież większość na swoim terenie ${ }^{20}$.

Ideologia demokratycznego „samorządu” służy przeto nie jednostce i jej wolności - jest bowiem jawnie kolektywistyczna — lecz uprawomocnieniu ekspansji władzy. Żyjąc w bałamutnym przeświadczeniu, że samo stanowi podmiot sprawujący rządy, społeczeństwo chętniej godzi się na państwową ingerencję w najrozmaitsze obszary życia ${ }^{21}$. Sięgając po terminologię marksistowską, Hoppe dodaje do tego, że w demokracji — na skutek dopuszczenia ogółu społeczeństwa do czerpania korzyści z polityki redystrybucyjnego rabunku — osłabieniu ulega świadomość klasowa rządzonych, tracących z pola widzenia swoją odrębność od klasy rządzącej22.

W swojej kontestacji ludowładztwa Rothbard powołuje się także na argumenty wypracowane $\mathrm{w}$ drugiej połowie XIX wieku przez amerykańskiego anarchoindywidualistę Lysandera Spoonera. Po pierwsze, aby móc mówić o rządzie opartym na zgodzie, wyraźnej aprobaty musieliby udzielić władzy wszyscy co do jednego obywatele, co oczywiście nigdy i nigdzie nie ma miejsca. Państwo, twierdzi Rothbard, to wytwór przemocy, nie kontraktu. Aby się o tym przekonać, wystarczy znieść przymus opodatkowania — wówczas okaże się, ilu podatników oddawałoby państwu swoje dochody dobrowolnie. Po drugie, sygnatariusze umowy społecznej byliby uprawnieni do działania wyłącznie we własnym imieniu podjęte przez nich zobowiązania polityczne ustawałyby z chwilą ich śmierci i nie mogłyby obejmować kolejnych pokoleń. Po trzecie, kiedy demokratyczna władza zostanie ustanowiona, sam akt wyborczy nie może być w żadnym razie postrzegany jako dobrowolny. Wyborca nie podejmuje wszak decyzji co do sprawy najbardziej fundamentalnej — samego istnienia państwa i demokracji; porusza się jedynie w wąskim spektrum narzuconych mu alternatyw, co upodobnia jego sytuację do pozycji ofiary napadu, której rabusie pozwalają dobrotliwie zdecydować, kto z nich ją ograbi. Nadto, skorzystanie z czynnego prawa wyborczego to akt nie tyle wolności, co ratunku: inni ludzie, wyposażeni w kartki wyborcze, sprawują nad jednostką tyranię, której dolegliwość może ona osłabić, jeśli sama weźmie udział w wyborach.

Z tego powodu, że człowiek, by ratować własne życie podczas bitwy zabiera życie innym ludziom, nie można twierdzić, że sam zdecydował się na udział w bitwie. Podobnież w przy-

${ }^{20}$ Ibidem.

21 M.N. Rothbard, Egalitaryzm jako bunt przeciwko ludzkiej naturze, przeł. K. Węgrzecki, Warszawa 2009, s. 105-106.

${ }^{22}$ H.-H. Hoppe, Demokracja..., s. 59. Szerzej na temat Hoppego teorii walki klas zob. idem, Ekonomia i etyka własności prywatnej. Studia z zakresu ekonomii politycznej i filozofii, przeł. K. Nowacki, Warszawa 2011, s. 127-148. 
padku głosowania — które jest zwykłym substytutem pocisku — jeśli człowiek korzysta z głosowania, ponieważ to jego jedyna szansa na samoobronę, nie można twierdzić, że bierze udział w tej formie współzawodnictwa z własnej woli — pisał Spooner ${ }^{23}$.

Po czwarte, wbrew teorii i własnym deklaracjom, w demokracji pośredniej deputowani do ciała ustawodawczego nie pełnią w rzeczywistości roli reprezentantów tych, którzy ich wybrali. Z chwilą zakończenia wyborów i ukonstytuowania się legislatywy korzystają oni z wolnego mandatu, prowadząc politykę i wchodząc w koalicje z innymi siłami wedle własnego uznania ${ }^{24}$.

\section{2) Demokratyczna wojna wszystkich przeciwko wszystkim}

Widzimy już, dlaczego zdaniem libertarian demokracja nie może mitygować antywolnościowej natury państwa. Jak jednak Hoppe utrzymuje w swojej znanej książce Demokracja — bóg, który zawiódt, nie dość na tym. Inaczej niż Rothbard, nieczyniący wyraźnych rozróżnień co do wpływu poszczególnych form państwa na eskalację lub deeskalację jego niegodziwych praktyk, niemiecki filozof obszernie dowodzi, że demokratyzacja stanowi cywilizacyjny regres, prowadząc do intensyfikacji etatystycznego zniewolenia.

W swoich analizach ustrojowych korzysta Hoppe z narzędzi ekonomicznych, częściowo podobnych do tych stosowanych w badaniach nad instytucjami politycznymi przez tzw. szkołę wyboru publicznego ${ }^{25}$. Punktem wyjścia jego argumentacji jest podział ustrojów politycznych na rządy własności prywatnej oraz własności publicznej. Pierwszy z nich to monarchia, w której panujący uznawany jest za prywatnego właściciela państwa. Rząd własności publicznej identyfikuje z kolei myśliciel z demokracją — systemem, w którym rządzący są nie właścicielami, lecz jedynie tymczasowymi zarządcami (ang. temporary caretakers) domeny publicznej, za właściciela państwa (suwerena) zaś uchodzi ogół obywateli. Do polityków w takim ustroju należy wyłącznie „bieżące użytkowanie” monopolu na przemoc i opodatkowanie, nie przysługuje im natomiast prawo do jego „wartości kapitałowej"26.

Podkreślenia wymaga fakt, że obie te konstrukcje nie mają charakteru pojęć empirycznych; są to raczej typy idealne, tworzące dwa ekstrema kontinuum obejmującego szereg historycznych form pośrednich, takich jak chociażby dziewiętnastowieczne europejskie monarchie konstytucyjne, $\mathrm{z}$ czasem - w miarę słabnięcia czynnika monarchicznego oraz rozszerzenia prawa wyborczego - przekształcające się w czyste demokracje, nawet przy zachowaniu de iure statusu monarchii

23 L. Spooner, Nie-Zdrada, przeł. S. Sękowski, Warszawa 2008, s. 28.

24 M.N. Rothbard, Etyka wolności..., s. 270-276; L. Spooner, op. cit., s. 25 n.

25 Literatura z obszaru teorii wyboru publicznego jest nadzwyczaj rozległa. Reprezentatywne dla tego nurtu analizy zawiera np. A. Downs, An Economic Theory of Democracy, New York 1957. Zob. także Teoria wyboru publicznego, red. J. Wilkin, Warszawa 2005.

${ }^{26}$ H.-H. Hoppe, Demokracja..., s. 86. 
parlamentarnych ${ }^{27}$. Rezultatem konsekwentnego stosowania kryterium własności państwa jest ponadto sklasyfikowanie przez Hoppego totalitarnych dyktatur komunistycznych, nazistowskich i faszystowskich jako demokracji. Ostatecznie wszak ani Adolf Hitler, ani Józef Stalin, ani inni totalitarni dyktatorzy nie cieszyli się pozycją prywatnych właścicieli swoich państw; stali na czele masowych partii politycznych, a w świetle teorii dostarczających legitymizacji ich władzy byli zaledwie reprezentantami Volku, rewolucyjnego proletariatu bądź innej dużej grupy społecznej traktowanej przez panującą ideologię jako obdarzona szczególną misją. Gwoli ścisłości dodajmy, że Hoppe nie rozpatruje nowoczesnych dyktatur jako wcieleń czystego typu demokracji — jak się wyraża, są to raczej reżimy „bliższe demokracji”. Najwidoczniej dostrzega on, że brak cyklicznej alternacji władzy w uczciwych wyborach oraz autokratyczny sposób sprawowania rządów przesuwają je na osi monarchia-demokracja w kierunku tej pierwszej, jakkolwiek nadal plasują się one bliżej ludowładztwa ${ }^{28}$.

Implikacje przedstawionych dystynkcji pojęciowych są według Hoppego doniosłe i wieloaspektowe. Odmienna struktura własności monopolu pociąga za sobą — przy podwójnym założeniu interesowności i racjonalności polityków zróżnicowanie typu bodźców, na jakie wystawieni są monarchiczni właściciele oraz demokratyczni zarządcy. Wolno przewidywać, że król lub książę będzie upatrywał w swoich ziemiach dobra kapitałowego, mającego w zamyśle służyć całym pokoleniom dynastii, co skłoni go do prowadzenia bardziej dalekowzrocznej, a więc - w ocenie libertariańskiego filozofa i ekonomisty — relatywnie liberalnej polityki. Daniny narzucane przez monarchę będą względnie niskie, biurokracja niewielka, zadłużenie i inflacja ograniczone, wojny zaś traktowane będą jako prywatne przedsięwzięcia monarchy, wobec których masom ludowym pozostaje zachować obojętność 29 .

Tymczasem demokratyczni zarządcy, nie mogąc partycypować w korzyściach z wartości kapitałowej kontrolowanego przez siebie państwa, obejmą swoim horyzontem planowania wyłącznie kwestie doraźne, starając się zarazem w swoim partykularnym interesie eksploatować społeczeństwo w sposób możliwie najbardziej intensywny, stosownie do kadencyjnego ograniczenia władzy. $\mathrm{W}$ rezultacie dojdzie do całkowitej lub niemal całkowitej deprecjacji wolności i własności. Maksymalizując swoje bieżące dochody, zarządcy nie będą znali

27 Ibidem, s. 50-54.

28 H.-H. Hoppe, Demokracja..., s. 62, przyp. 40. Zob. także Antydemokrata - wróg publiczny numer jeden - wywiad z Hansem-Hermannem Hoppe, http://liberalis.p1/2007/04/01/wywiad-z-hansem-hermannem-hoope/ (dostęp: 26.12.2017). Znane są oczywiście wyjątki od tej reguły: na Castrowskiej Kubie i w Północnej Korei Kimów doszło, jak wiadomo, do dziedziczenia władzy, co zbliża panujące tam reżimy do systemów monarchicznych.

29 Ponieważ niniejszy artykuł poświęcony jest problematyce demokracji, nie zaś monarchii, odstępujemy w nim od obszerniejszej prezentacji poglądów Hoppego na ustrój monarchiczny. Omówienie takie znajdzie czytelnik w tekście: N. Slenzok, Hansa-Hermanna Hoppego libertariańska rehabilitacja monarchii. Analiza metodologiczna, „Societas et Ius” 2016, nr 5, s. 11-132. 
umiaru w obciążaniu społeczeństwa podatkami. Jednocześnie jako liderzy wielotysięcznych bądź nawet wielomilionowych stronnictw politycznych dopuszczą do udziału w zyskach szerokie grono popleczników i lobbies, co poskutkuje hipertrofią biurokracji, legislacji i rozmaitych polityk publicznych, krok po kroku anektujących kolejne dziedziny ludzkiego życia. Demokracja wpłynie ponadto niekorzystnie na obraz wojen. Prywatne kampanie dawnych monarchów ustąpią masowym konfliktom toczonym przy udziale całych społeczeństw, których celem będzie biologiczna anihilacja narodu uznanego za wrogi, a nieliczne wojska złożone $\mathrm{z}$ wasali króla zostaną zastąpione przez motywowane nacjonalistyczną ideologią powszechne armie $\mathrm{z}$ poboru ${ }^{30}$.

Nie mniej szkodliwy wpływ ma zdaniem Hoppego demokracja wywierać na postawy społeczeństwa. Poddane rządom ludowładczego reżimu, również i ono zredukuje zasięg czasowy swojego planowania. Autor Demokracji... ilustruje tę tezę następującym eksperymentem myślowym: wyobraźmy sobie, że proklamowany zostaje demokratyczny rząd światowy. Wziąwszy w rachubę liczebność poszczególnych narodów, można domniemywać, że zwycięstwo w powszechnej elekcji przeprowadzonej przez taki globalny reżim odnieśliby przedstawiciele Chińczyków i Hindusów. Wyłoniony przez nich rząd zapewne nałożyłby olbrzymie podatki na obywateli bogatych państw Zachodu, dokonując gigantycznego przymusowego transferu środków na rzecz względnie ubogiej ludności Chin oraz Indii. Tym samym zostałaby ustanowiona światowa machina redystrybucji, która odtąd - sprowadzając Amerykanów i Europejczyków do rangi niewolników stale podmywałaby fundamenty prawa własności, a co za tym idzie - wolności i rozwoju gospodarczego ${ }^{31}$.

To, czego dopuściłby się hipotetyczny rząd światowy, zdaniem Hoppego odbywa się permanentnie także i obecnie, tyle że w mikroskali państw narodowych. Filozof powiada:

Jeśli chodzi o moralność, to trzeba stale przypominać, że zgodnie z regułami demokracji A i B mogą połączyć siły i okraść $\mathrm{C}, \mathrm{C}$ do spółki z A może obrabować $\mathrm{B}$, zaś $\mathrm{B}$ i $\mathrm{C}$ mogą z kolei układać się przeciwko A itd. Nie ma to oczywiście nic wspólnego ze sprawiedliwością, lecz po prostu urąga przyzwoitości ${ }^{32}$.

Jako przyczynę nasilania się redystrybucyjnej tendencji demokracji, wskazuje Hoppe prawidłowość określaną przez ekonomistów mianem „tragedii wspólnoty” albo „tragedii wspólnego pastwiska” (ang. tragedy of commons) ${ }^{33}$. Polega ona na tym, że ilekroć dany zasób ekonomiczny jest przedmiotem własności wspólnej, korzystające zeń jednostki — kierując się racjonalnym interesem własnym — nie mają motywacji do eksploatowania go w sposób oszczędny, z uwzględ-

\footnotetext{
${ }^{30}$ H.-H. Hoppe, Demokracja ..., s. 87-96.

31 Ibidem, s. 147.

32 Ibidem, s. 157-158.

33 Ibidem, s. 148.
} 
nieniem jego długoterminowej wartości kapitałowej. Przeciwnie, w ich interesie leży natychmiastowa i intensywna eksploatacja zasobu, pozwalająca uprzedzić wykorzystanie go przez pozostałych. W systemie demokratycznym oznacza to tendencję do porzucania produktywnych acz wymagających nakładów czasu i pracy zajęć na rzecz czerpania profitów z realizowanej przez państwo redystrybucji dóbr - za sprawą demokracji „umocni się skłonność do przechodzenia z grupy producentów do grupy nieprodukujących" ${ }^{34}$. Powodem tego jest fakt, że produktywne czynności, nieuchronnie związane z ponoszeniem kosztów, stają się w obliczu „tragedii wspólnoty” bardziej kosztowne i ryzykowne, a zatem spada ich atrakcyjność na tle nieproduktywnych lub zgoła pasożytniczych alternatyw ${ }^{35}$.

Odnotować trzeba, że wbrew sugestii płynącej z kontrfaktycznego przykładu rządu światowego, Hoppe nie utrzymuje, jakoby demokratyczna redystrybucja polegała z konieczności na przejmowaniu dóbr należących do mniej licznych bogatych przez liczniejszych biednych. W rzeczywistości trend ma być według autora Demokracji... odwrotny. Zalety ducha umożliwiające sukces na nieskrępowanym rynku pokrywają się bowiem przynajmniej po części z cechami wymaganymi od przywódców i członków organizacji sięgających po środki polityczne celem skierowania do siebie strumienia redystrybucji. Zarówno w gospodarce wolnorynkowej, jak i w demokratycznej grze politycznej ludzie zaradniejsi, bardziej zdeterminowani i dalekowzroczni osiągają przewagę nad mniej zaradnymi, mniej zdeterminowanymi i krótkowzrocznymi. Teza ta prowadzi Hoppego - podobnie zreszta jak Rothbarda $^{36}$ - do uznania żelaznego prawa oligarchii Roberta Michelsa. Głównymi beneficjentami redystrybucyjnych programów w optyce niemieckiego ekonomisty są plutokraci (zwłaszcza sektor bankowy i tzw. kompleks przemysłowo-zbrojeniowy) korzystający ze wsparcia roszczeniowo zorientowanych najuboższych, największe ciężary zaś spadają w demokracji na barki klasy średniej ${ }^{37}$.

Jak przekonuje Hoppe, demokracja okazuje się najskuteczniejszą formą rządów z punktu widzenia elementarnego zadania państwa, jakim jest zapewnienie sobie legitymizacji. Jednym z dwóch — obok etatystycznej ideologii — filarów, na których wspiera się państwo, jest bowiem zdaniem Hoppego korumpowanie części społeczeństwa w drodze dopuszczenia jej do udziału w procederze wyzysku. Wszelako każde działanie ekonomiczne obarczone jest tzw. kosztem alternatywnym - wykorzystanie rzadkiego zasobu w celu X oznacza, że nie można już zatrudnić go do realizacji celu Y. W konsekwencji za każdym razem, gdy państwo zaspokaja potrzeby jakiejś frakcji swojej klienteli, wywołuje niezadowolenie u innej frakcji, której interesy zostały zlekceważone. Demokracja natomiast przedstawia sobą tę zaletę dla rządzących, że przynajmniej oficjalnie

\footnotetext{
34 Ibidem, s. 72.

35 Ibidem, s. 69-72, passim. Zob. także idem, Teoria socjalizmu i kapitalizmu. Ekonomia, polityka i etyka, przeł. P. Nowakowski, Wrocław 2015, s. 7-19, passim.

36 M.N. Rothbard, O nowa wolność..., s. 77.

37 H.-H. Hoppe, Demokracja..., s. 148-150; idem, Krótka historia człowieka..., s. 84-87.
} 
do procedur decyzyjnych dopuszczeni zostają wszyscy obywatele bez wyjątku. Poniósłszy porażkę w politycznej walce o zasoby, przegrani mogą więc rozsądnie mieć nadzieję na sukces przy innej okazji. Demokratyczna polityka staje się przeto areną, na której niezliczone grupy rywalizują między sobą o prawo do wzajemnego okradania i zniewalania. Historyczne skutki tego stanu rzeczy mogą być i są wyłącznie opłakane: erozja libertariańskich pryncypiów wolności i własności postępuje w demokracji na bezprecedensową skalę. Jakkolwiek wywody Hoppego mają charakter stricte teoretyczny, sięga on po mające je ilustrować egzemplifikacje empiryczne. Jak wykazuje, w erze nazywanej przez niego „demokratyczno-republikańską", która miała rozpocząć się mniej więcej w roku 1918, poziom opodatkowania, inflacji i regulacji sięgających każdego aspektu życia radykalnie przewyższył to, co działo się pod rządami monarchów ${ }^{38}$. Filozof pisze z wyraźnym zgorszeniem:

Każdy szczegół życia prywatnego, posiadania i nabywania własności, handlowania i zawierania kontraktów obwarowany jest stosem piętrzących się przepisów prawnych (legislacyjnych). W imię społecznego, publicznego czy narodowego bezpieczeństwa nasi zarządcy usiłują „chronić” nas przed globalnym ociepleniem i oziębieniem, przed wyginięciem zwierząt i roślin, przed mężami i żonami, przed rodzicami i prawodawcami, przed biedą, chorobami, katastrofami, ignorancją, uprzedzeniami, rasizmem, seksizmem i setkami innych ,wrogów publicznych" i niebezpieczeństw ${ }^{39}$.

Całą zaś abominację Hoppego wobec demokracji adekwatnie odzwierciedla jeden z bardziej znanych passusów, jakie wyszły spod jego pióra:

Podstawę i istotę wolności stanowi instytucja własności prywatnej. Prywatna - wyłączna własność jest logicznie niekompatybilna z demokracją — rządami większości. Demokracja nie ma nic wspólnego z wolnością. Jest to łagodny wariant komunizmu i w historii idei rzadko kiedy uważano ją za coś innego ${ }^{40}$.

\section{3) Fiasko liberalnych hamulców}

Zwyczajowo przyjmuje się, że reżim polityczny występujący we współczesnych państwach Zachodu jest w istocie ustrojem mieszanym — syntezą elementów demokratycznych (zasada suwerenności ludu) z pryncypiami klasycznego liberalizmu (zasady wolności jednostki, pluralizmu, praworządności, podziału i równowagi władz), w której centralne wartości liberalnego credo - prawa jednostki ludzkiej — chronione są przed naruszeniami za pomocą instytucji powściągających władzę większości. Jak przekonują Rothbard i Hoppe, zabezpieczenia te są jednak iluzoryczne, a władza demokratycznego państwa nad człowiekiem ma $\mathrm{z}$ natury charakter niepohamowany.

38 H.-H. Hoppe, Demokracja..., s. 97-114.

39 Ibidem, s. 139.

${ }^{40}$ H.-H. Hoppe, Krótka historia czlowieka..., s. 166. 
Zasadę rządów prawa krytykują libertarianie w dwójnasób. Nade wszystko nie podzielają oni stanowiska reprezentowanego przez gros liberałów, takich jak Monteskiusz czy Friedrich August von Hayek, zgodnie z którym wolność polega na byciu związanym wyłącznie przez prawo; jeśli to ostatnie spełnia określone warunki, takie jak ogólność i bezstronność, wolno w myśl tego poglądu traktować jego normy jako niesprzeczne $\mathrm{z}$ wolnością ${ }^{41}$. Twierdzenie to jest rzecz jasna nie do przyjęcia dla obstających za etycznym absolutyzmem libertarian. Koncepcję Hayeka, głoszącą, że dowolną aktywność państwa da się pogodzić z wolnością, o ile tylko jego ingerencja przybiera postać uniwersalnej normy prawnej, co pozwala działającym podmiotom na dostosowanie do niej swoich planów, tak jak czynią to one w odniesieniu do praw przyrody, Hoppe określa wprost jako „terminologiczne hokus-pokus" ${ }^{2}$. Rothbard natomiast kreśli redukcję ad absurdum: załóżmy, że społeczeństwo

\begin{abstract}
jest rządzone za pomocą ogólnych Hayekowskich zasad, stosowanych równo wobec wszystkich, np. że każdy musi być zniewolony przez okres jednego roku w ciągu każdych trzech lat, nikt nie może krytykować rządu pod groźbą kary śmierci, nie można pić napojów alkoholowych, każdy musi padać na kolana w stronę Mekki trzy razy dziennie o określonych godzinach, musi też nosić zielony strój itd. Takie społeczeństwo, mimo iż spełnia wszystkie Hayekowskie kryteria nieprzymusowego systemu prawnego, jest na wskroś despotyczne i totalitarne ${ }^{43}$.
\end{abstract}

Innymi słowy, jak powiada pokrewny libertarianom myśliciel Anthony de Jasay, liczą się nie same rządy prawa, lecz dobre prawo ${ }^{44}$. Prawo dobre zaś to w libertariańskiej perspektywie prawo ufundowane na zasadzie nieagresji — imperatywie honorowania nieograniczonego prawa własności.

Jednocześnie nawet dobre prawo nie może jednakże utrzymać się długo, jeżeli na jego straży stoi działający w oparciu o przymus monopolista, jakim jest państwo. Zarówno Rothbard, jak i Hoppe chętnie cytują francuskiego politologa Bertranda de Jouvenela, który w swoim klasycznym Traktacie o władzy dowodził, że wszystkie ideologie wypracowane pierwotnie celem nałożenia ograniczeń na ekspansję władzy stawały się z czasem propagandowym instrumentem dostarczającym jej uzasadnienia. Zasady praworządności i konstytucjonalizmu dzielą w tym kontekście los koncepcji boskiego pochodzenia władzy królów oraz zasady suwerenności ludu. Nawet najbliższa libertariańskim pryncypiom konstytucja

41 Monteskiusz, O duchu praw, przeł. T. Boy-Żeleński, Kraków 2016, s. 170; F.A. Hayek, op. cit., s. $141 \mathrm{n}$.

42 H.-H. Hoppe, F.A. Hayek on Government and Social Evolution. A Critique, „The Review of Austrian Economics" 1994, vol. 1 (7), s. 69.

43 M.N. Rothbard, Etyka wolności..., s. 350-351.

44 A. de Jasay, The State, Indianapolis 1998, http://www.econlib.org/library/LFBooks/Jasay/ jsyStt20.html\#4.1 Fixed Constitutions (dostęp: 28.12.2017). 
będzie więc interpretowana tak, by nadać pozory legalności naruszeniom praw jednostki ${ }^{45}$.

Jako iluzoryczną znajdują libertarianie również zasadę podziału i równowagi władz ze szczególnym uwzględnieniem ideału niezawisłości sądów. Konstytucyjna kontrola legislacji sprawowana przez sądy i trybunały to tylko kolejne ideologiczne narzędzie będące źródłem legitymizacji dla aktów przemocy ze strony państwa. Prócz bowiem opisanego już korumpowania społeczeństwa, tak aby politycznie relewantna część społeczeństwa związana była z państwem siecią wspólnych interesów, Lewiatan dla umocnienia swojego panowania potrzebuje ideologii (pojmowanej w duchu marksistowskim jako fałszywa świadomość) skutecznie przekonującej opinię publiczną o legitymowalnym statusie władzy. Opatrzenie gwałcących wolność ustaw świadectwem prawomocności wydanym przez organ kontroli konstytucyjnej — rzekomego strażnika praw i wolności doskonale sprawdza się usypianiu czujności rządzonych ${ }^{46}$.

Dlaczego należy zdaniem libertarian oczekiwać, że sąd konstytucyjny będzie występował raczej jako sojusznik władzy niżeli protektor wolności? Wynika to stąd, że wszystkie segmenty Monteskiuszowego podziału władz — legislatywa, egzekutywa i judykatywa - stanowią agencje tej samej instytucji: państwa. Fakt ten — tyleż trywialny, ileż częstokroć pomijany w apologetycznej wobec liberalnej demokracji literaturze - jest brzemienny w skutki. Po pierwsze, oznacza on, że w sporach pomiędzy obywatelami a państwem sądy przyjmują pozycję sędziego we własnej sprawie, co musi stwarzać zagrożenie ferowania stronniczych wyroków ${ }^{47}$. Po wtóre, w reżimach demokratycznych rozdział pomiędzy poszczególnymi rodzajami władz nigdy nie jest ścisły — zawsze pozostają one z sobą w pewnych zależnościach, na przykład wynikających z kreacyjnych funkcji legislatywy wobec władz wykonawczej i sądowniczej ${ }^{48}$. Jest to, dodajmy, sytuacja odmienna od tej, w której rozwinął swoją teorię Monteskiusz. Żyjąc w XVIII wieku, filozof postrzegał wszak trzy człony władzy jako zakorzenione w odrębnych klasach społecznych — z królem stojącym na czele egzekutywy czy też legislatywą podzieloną wzorem angielskim między arystokrację i burżuazję ${ }^{49}$. Tak zaplanowany podział władz miał z pewnością silniejsze umocowanie niż dzisiejszy, przebiegający między instytucjami obsadzanymi według egalitarnego kryterium powszechnego dostępu do urzędów. Jak bowiem zauważa Jasay, skuteczność formalnej równowagi władz może być jedynie funkcją realnej równowagi stojących za nimi sił społecznych ${ }^{50}$.

45 M.N. Rothbard, Egalitaryzm..., s. 112-113. Zob. szerzej B. de Jouvenel, Traktat o władzy, przeł. K. Śledziński, Warszawa 2013, s. 42-61.

46 M.N. Rothbard, Egalitaryzm..., s. 113. Zob. też A. de Jasay, op. cit.

47 H.-H. Hoppe, Demokracja..., s. 359-360.

48 Ibidem.

49 Monteskiusz, op. cit., s. 172-201.

50 A. de Jasay, op. cit. 
Wreszcie wszystkich członków klasy rządzącej, niezależnie od tego, czy są ustawodawcami, członkami rządu, czy też sędziami, łączy wspólny interes sprowadzający się do rozszerzania kontroli państwa nad społeczeństwem. Jak powiada Hoppe:

Konstytucyjny podział władzy nie ma tu praktycznie żadnego znaczenia. Dwa lub trzy złe czynniki nie złożą się na nic dobrego. Przeciwnie, doprowadzą do rozprzestrzenienia, nagromadzenia i spotęgowania $\mathrm{zła}^{51}$.

Rzeczywistą rolę konstytucjonalizmu oraz równowagi i podziału władz trafnie więc ujmuje Jasay, pisząc o nich jako o pasie cnoty, do którego klucz znajduje się w zasięgu ręki damy ${ }^{52}$.

Za najlepszą empiryczną ilustrację zawodności liberalnych hamulców, a zarazem utopijności wszelkich liberalnych projektów rządu ograniczonego może według libertarian służyć przykład Stanów Zjednoczonych Ameryki Północnej. Utworzone jako konstytucyjna republika o ściśle limitowanych kompetencjach, w przeciągu niespełna dwu stuleci przeistoczyły się one w państwo klasyfikowane przez Hoppego jako socjaldemokratyczne ${ }^{53}$, w którym władza przejmuje około $40 \%$ dochodów obywateli, najróżniejsze aspekty życia podlegają drobiazgowej kontroli urzędników, ambicją rządzących zaś jest sprawowanie hegemonicznej kontroli nad całym światem ${ }^{54}$.

Historyczny trend ekspansji władzy, widoczny w dziejach cywilizacji zachodniej począwszy od wczesnego średniowiecza ${ }^{55}$, nie jest $\mathrm{w}$ żadnym razie dziełem przypadku. Alfred G. Cuzan formułuje nawet prawa rozrostu i koncentracji władzy, które proponuje zaliczać w poczet ogólnych praw nauki o polityce, funkcjonujących na podobieństwo elementarnych praw ekonomii w rodzaju prawa podaży i popytu ${ }^{56}$. Zostawmy na boku metodologiczną kontrowersję, czy tego typu twierdzenia mogą naprawdę uchodzić za prawa nauki o statusie epistemolo-

51 H.-H. Hoppe, Demokracja..., s. 359.

52 A. de Jasay, op. cit.

53 Państwo socjaldemokratyczne - a dokładniej „socjalizm typu socjaldemokratycznego” definiuje Hoppe, podając jego dwie dystynktywne cechy: „Po pierwsze, socjalizm socjaldemokratyczny, co pozytywnie odróżnia go od tradycyjnego socjalizmu marksistowskiego, nie zakazuje prywatnego posiadania środków produkcji, a nawet godzi się na to, by wszystkie środki produkcji były w prywatnym posiadaniu — z wyjątkiem jedynie edukacji, dróg i komunikacji, centralnej bankowości oraz policji i sądów. [...] Po drugie jednak, żaden właściciel środków produkcji nie posiada w sposób prawowity całości dochodu, jaki uzyskuje dzięki użytkowaniu swoich środków produkcji, ani też żaden właściciel nie może podejmować decyzji w kwestii tego, jaką część całkowitego dochodu przeznaczyć na konsumpcję i inwestycje. Część dochodu uzyskanego z produkcji należy w sposób prawowity do społeczeństwa, któremu jest przekazywana, a następnie, zgodnie z koncepcjami egalitaryzmu czy sprawiedliwości dystrybutywnej, redystrybuowana pomiędzy jego poszczególnych członków”. H.-H. Hoppe, Teoria socjalizmu i kapitalizmu..., s. 46.

54 H.-H. Hoppe, Demokracja..., s. 361-362.

55 Zob. B. de Jouvenel, op. cit., passim.

56 A.G. Cuzan, Some Principles of Politics, „Libertarian Papers” 2017, vol. 2 (9), s. 189-190. 
gicznym odpowiadającym prawom nauk przyrodniczych. Czym należy zdaniem libertarian thumaczyć przemożność tendencji władzy do ekspansji i koncentracji? Kluczowym założeniem jest tu bez wątpienia racjonalna (w sensie racjonalności instrumentalnej) interesowność członków klasy rządzącej. U Hoppego — jak już wspomnieliśmy - zostaje ono wyartykułowane explicite, natomiast u Rothbarda ma charakter milczący. Na drugą przesłankę wskazuje z kolei Jasay: jest to asymetria sił pomiędzy władzą a społeczeństwem ${ }^{57}$. Kierując się egoistycznymi motywami, klasa rządząca będzie zawsze lub niemal zawsze dążyła do rozszerzania swojego imperium kosztem poddanych, a ponieważ co do zasady dysponuje ona nad nimi przewagą siły, jej cel będzie na ogół skutecznie realizowany.

\section{Komentarz i konkluzje}

Wydaje się, że zaprezentowane poglądy libertarian uzasadniają postawienie wniosku, że demokracja postrzegana jest na ich gruncie jako ustrój totalitarny, którego immanentna specyfika wiąże się z dążeniem do całkowitego podporządkowania jednostki ludzkiej kontroli państwa (zniesienia autonomii sfery prywatnej), czemu nie mogą zapobiec jakiekolwiek wewnątrzsystemowe bariery. Choć niepodzielającemu osnutej wokół kategorii własności libertariańskiej etyki czytelnikowi wizja ta może jawić się jako przesadna, jest ona na pewno koherentna $\mathrm{z}$ bronionym przez libertarian systemem wartości i w jego świetle staje się zrozumiała. Co nie mniej istotne, twierdzenia Hansa-Hermanna Hoppego rozciągają zakres denotacji terminu „demokracja” na ustroje powszechnie uznawane za totalitarne: komunistyczny, faszystowski i nazistowski. Clue libertariańskiej koncepcji totalitarnej demokracji należałoby tedy upatrywać w dwu tezach: 1 Talmonowskie rozróżnienie pomiędzy totalitarną i liberalną demokracją jest nie do obrony. W istocie totalitarny charakter ma każda demokracja. 2) Można mówić nie o demokracji liberalnej i totalitarnej, lecz o dwóch odmianach esencjalnie totalitarnego reżimu demokratycznego: „czystej” demokracji opartej na równym i powszechnym prawie wyborczym oraz odchylonej od typu idealnego demokracji dyktatorskiej, w której powszechny dostęp do aparatu władzy realizowany jest poprzez masowość partii hegemonicznej oraz względnie inkluzywny charakter rozbudowanego aparatu władzy (biurokracji, tajnych służb etc.). Dla porządku dodajmy, że nie jest to - przypuszczalnie także w intencji Rothbarda i Hoppego - wyczerpujący podział logiczny pojęcia demokracji. W swoich rozważaniach bowiem nie zajmują się oni chociażby klasyczną demokracją ateńską, tradycyjnie stanowiącą zasadniczy model porównawczy dla teoretyków demokracji.

Za Pawłem Nowakowskim trzeba zaznaczyć, że sam Hoppe nie rozdziela starannie w swoich analizach wątków odnoszących się do obu typów demokracji, toteż użycie nazwy „demokracja” w jego pracach obarczone jest błędem

57 A. de Jasay, op. cit. 
ekwiwokacji — raz myśliciel skupia się na etycznych i ekonomicznych skutkach powszechnego prawa wyborczego, innym razem zaś operuje szerszym pojęciem demokracji jako „rządu własności publicznej”, pod które podpadają również nowoczesne systemy dyktatorskie ${ }^{58}$. O wiele więcej miejsca w rozważaniach Hoppego - co znajduje odbicie także w naszym artykule — zajmuje przy tym pierwsza z owych grup zagadnień. Trzeba uznać to za słabość jego teorii. Sklasyfikowanie komunistycznych czy faszystowskich dyktatur jako na swój sposób demokratycznych nie jest wprawdzie całkowicie oryginalne - podobne tezy wysuwali przedtem Talmon czy też Aleksander Zinowiew ${ }^{59}$. Godzi się także pamiętać, że komuniści, naziści i faszyści ze swojej strony przedstawiali się jako stronnictwa demokratyczne, a nawet urzeczywistniające autentyczną, niezafałszowaną przez plutokratów i inne wrogie ludowi siły demokrację, w komunizmie rozszerzoną ze sfery politycznej na całość życia społecznego, zwłaszcza zaś na gospodarkę. W polskiej literaturze poglądu o demokratycznej istocie dwudziestowiecznych totalitaryzmów przekonująco broni natomiast Jacek Bartyzel. Odnośnie do sowieckiego komunizmu pisze on:

Naturą ludowładztwa była tu zarówno nie znana nigdy i nigdzie dotąd masowość terroru (gdyż jeśli mniej więcej jedna trzecia ludności była w łagrach, to również mniej więcej tyle samo liczyła populacja ich strażników, partycypujących tedy w jakimś stopniu we władzy - i to władzy nad życiem i śmiercią!), jak i jego egalitaryzm (droga z ,dna piekieł” na szczyty władzy i tak samo w odwrotną stronę była w każdej chwili otwarta dla każdego). Bodaj jeszcze bardziej „,naturalną formę” autentycznej demokracji ludowej [wyróżnienie - N.S.] wyrażała powszechność systemu donosicielstwa i demaskowania, jako samorzutna, choć stymulowana z góry, aktywność mas ${ }^{60}$.

Mimo to takie postawienie sprawy musi niewątpliwie budzić zdziwienie odbiorcy przyzwyczajonego do dominującej we współczesnej politologii siatki pojęć, w której kategorie totalitaryzmu i demokracji pozycjonowane są jako przeciwstawne. Tym bardziej więc należałoby opatrzyć tak kontrowersyjne tezy obszerniejszym uzasadnieniem i zasadniczo głębiej rozpatrzyć naturę reżimów dyktatorskich. U Hoppego tymczasem kwestie te są zaledwie sygnalizowane $\mathrm{w}$ formie przypisu rzeczowego.

Jeśli zaś chodzi o identyfikację liberalnej demokracji jako reżimu totalitarnego, to wbrew apodyktycznej manierze (charakteryzującej zwłaszcza wywody Hoppego) wypowiedzi libertariańskich myślicieli na ten temat cechuje najwyraźniej pewna ambiwalencja. Jak już zauważono, nie posługują się oni expressis verbis określeniem „demokracja totalitarna”, co może sugerować wahanie co do jego adekwatności w odniesieniu do demokracji liberalnej. Jako znak ambiwalencji

58 P. Nowakowski, Dlaczego rządzą źli? O krytyce demokratycznych zarządców w filozofii politycznej Hansa-Hermanna Hoppego, „Dialogi Polityczne” 2010, nr 13, s. 276-277.

59 A. Zinowiew, Rosja i Zachód, przeł. N.B. I J.H. /II obieg/ Warszawa 1984, s. 85 - cyt. za: J. Bartyzel, op. cit., s. 36, przyp. 71.

60 J. Bartyzel, op. cit., s. 36, przyp. 71. 
można także odczytywać cytowane już dictum Hoppego o demokracji jako „tagodnym [wyróżnienie - N.S.] wariancie komunizmu". Również prowadząc rozważania o rozmaitych odmianach socjalizmu (definiowanego szeroko jako każdy system zinstytucjonalizowanego łamania praw własności), Hoppe systematycznie odróżnia gospodarkę „socjalizmu typu sowieckiego” od towarzyszącego liberalnej demokracji „socjalizmu typu socjaldemokratycznego”, spośród których charakter wyraźnie dotkliwszy z punktu widzenia etyki i ekonomii praw własności przypisuje temu pierwszemu ${ }^{61}$. Ale dlaczego demokracja jest wariantem łagodnym? Co decyduje o jego łagodności? Dlaczego pod jej panowaniem nie wprowadza się komunizmu, czyli — w terminologii Hoppego — socjalizmu typu sowieckiego? Pytanie to wolno traktować jako odsłonę uniwersalnego problemu: jeśli władza w ogólności wykazuje nieodparte dążenie do rozrostu, to wyjaśnienia — jak słusznie stwierdza Jasay — wymaga fakt, że jej pęd bywa jednak powstrzymywany ${ }^{62}$.

Najwyraźniej więc sam Hoppe nie traktuje rygorystycznie własności państwa jako jedynego czynnika rozstrzygającego o jego charakterze i jakości. Demokracja ma stanowić łagodną odmianę komunizmu, mimo że własność rządu jest w obu przypadkach publiczna. Być może zatem istnieją inne mechanizmy, limitujące demokratyczny pęd do panowania pomimo jej publicznego statusu?

Sądzimy, że należy wymienić tu trzy czynniki, z których pierwsze dwa można określić jako systemowe, trzeci zaś jako ideologiczny. Pierwszy czynnik systemowy jest związany z symplifikacją zawartą w stanowisku takich autorów jak Hayek czy Kuehnelt-Leddihn, całkowicie rozgraniczającym dziedziny liberalizmu (wolność jednostki, ograniczenia władzy) i demokracji (suwerenność ludu i uźródłowienie władzy w ludzie), z czego wprost wynika możliwość totalitarnej demokracji. Nie kwestionując tej możliwości w ogóle, uznajemy za nietrafione identyfikowanie demokracji opartej na powszechnym prawie wyborczym jako jej aktualizacji. Uproszczenie dystynkcji Hayeka i Leddihna polega na tym, że jak zauważa Robert Dahl — samo zachodzenie cyklicznej alternacji władzy na skutek wolnych wyborów (konstytutywny atrybut demokracji w tzw. realnej definicji Josepha Schumpetera ${ }^{63}$ ) pociąga za sobą — o ile wybory są naprawdę wolne i uczciwie — gwarancję pewnego zakresu swobód jednostkowych, które dają się opisać zarówno jako pozytywne wolności polityczne, jak i jako składniki liberalnej wolności negatywnej (a w perspektywie libertariańskiej: jako derywaty prawa własności i auto-własności). Jako przykłady można wymienić wolność słowa i mediów, swobodę zrzeszania się czy też prawo do demonstracji ${ }^{64}$. W tym miejscu warto odnotować jeszcze jedną niejasność tkwiącą w diagnozach demokracji,

61 H.-H. Hoppe, Teoria socjalizmu i kapitalizmu..., s. 7-66.

62 A. de Jasay, op. cit.

63 J.A. Schumpeter, Kapitalizm, socjalizm, demokracja, przeł. M. Rusiński, Warszawa 2009, s. $336 \mathrm{n}$.

64 R. Dahl, Demokracja i jej krytycy, przeł. S. Amsterdamski, Warszawa 2012, s. 131-132. 
rozwijanych przez Hoppego. Otóż z jednej strony obstaje on przy pochodzącej od klasycznych liberałów kategorii tyranii większości (widać to choćby w cytowanym stwierdzeniu o konflikcie pomiędzy wolnością a rządami większości), $\mathrm{z}$ drugiej jednak poprawnie rozpoznaje, że w praktyce demokracja oznacza nie tyle rządy większości, ile rywalizację wielu, nierzadko mniejszościowych grup interesu o publiczne zasoby, przez Dahla określaną mianem „poliarchii”"65. Uczciwa konkurencja pomiędzy nimi, prowadzona przede wszystkim na podstawie wyników wyborów, jakkolwiek istotnie prowadzi do naruszeń libertariańskich pryncypiów, o jakich pisze Hoppe, oprócz tego presuponuje logicznie ochronę przed przynajmniej niektórymi takimi naruszeniami.

Drugi z czynników systemowych to z kolei trafnie krytykowana przez libertarian za swoją zawodność zasada podziału i równowagi władz. Przychylając się do ich argumentacji, godzi się zarazem stwierdzić, że słabość nałożonych na woluntaryzm ludu liberalnych zabezpieczeń nie jest równoważna zupełnej nieprzydatności, jaką otwarcie imputują im Rothbard i Hoppe. Twierdzić, że w dalekiej perspektywie władza będzie stopniowo przełamywała stojące na jej drodze bariery, to nie to samo, co uznać, że barier w ogóle nie warto stawiać. Nawet jeśli kierunek długoterminowych zmian jest dla libertarian niekorzystny, to nie zmienia to faktu, że wielokrotnie poszczególne segmenty władzy rzeczywiście ograniczają się nawzajem: sądy konstytucyjne kwestionują ustawy parlamentów, parlamenty uchwalają budżety udaremniające plany egzekutywy etc. Nawiasem mówiąc, można stwierdzić, że z pozycji libertariańskich na pozytywną ocenę zasługują rozwiązania ustrojowe bynajmniej niemieszczące się w klasycznie pojętej koncepcji podziału i wzajemnej kontroli władz, a mianowicie cechujący ustroje Republiki Francuskiej i Rzeczypospolitej Polskiej dualizm władzy wykonawczej $^{66}$. Wychodząc z radykalnie antyetatystycznych przesłanek libertarianizmu, należy bowiem uznać, że paraliż decyzyjny, do jakiego może dochodzić w warunkach kohabitacji prezydenta i szefa rządu wywodzących się z różnych stronnictw politycznych, nie jest - jak chcą krytycy tej sytuacji — wadą, lecz zaletą rozdzielenia kompetencji egzekutywy pomiędzy dwa ośrodki.

Wreszcie, czynnik ideologiczny stanowi piętno, jakie na kulturze świata zachodniego wywarła myśl liberalizmu. Genetycznie wywodzące się z niego składniki współczesnej demokracji liberalnej, takie jak zasada pluralizmu i ochrony praw mniejszości nie mają co prawda - jak celnie punktują krytycy demokracji — rodowodu w ideologii demokratycznej, niemniej jednak w potocznej świadomości, a nawet w obszarze refleksji naukowej, trwale się z nią zrosły.

Nie kto inny, jak właśnie autorzy libertariańscy słusznie eksponują doniosłą rolę, jaką w procesie legitymizacji władzy odgrywa opinia publiczna. Istnienie każdego państwa stoi ostatecznie na fundamencie powszechnych przekonań;

65 Ibidem, passim.

66 A. Antoszewski, System polityczny RP, Warszawa 2012, s. 72-87. 
żaden rząd, monarcha ani dyktator nie panuje nad podporządkowanym sobie krajem siłą własnych rąk; jeśli na przykład armia amerykańska wykonuje rozkazy swojego prezydenta, to dzieje się tak dlatego, że jej żołnierze podzielają obecne w ich kulturze przekonanie o prawomocności jego władzy ${ }^{67}$. Ten powtarzany za Éttiennem de la Boétiem i Davidem Humem pogląd dostarcza nie tylko wiedzy na temat mechanizmów funkcjonowania państwa, ale też praktycznej wskazówki odnośnie do zapobiegania ekspansji władzy. Jeśli, jak pisał de la Boétie, państwo dysponuje władzą tylko w takim zakresie, w jakim ją przekażą jego poddani ${ }^{68}$, to kluczowym środkiem ograniczania jego rozrostu musi być umacnianie liberalnych (w ujęciu klasycznym) prądów w opinii publicznej. W tym kontekście nie może nie dziwić dezynwoltura, z jaką Hoppe wypowiada się o konstytucji USA jako źródle dumy narodowej Amerykanów, nazywając ją bez ogródek ,fatalną pomyłką" ${ }^{\prime 99}$. Niemiecki myśliciel nie dostrzega, zdaje się, znaczenia amerykańskiego przywiązania do pryncypiów skonstruowanej pod wpływem klasyczno-liberalnych ideałów konstytucji dla wyników konfrontacji pomiędzy państwem a wolnością. Ujawnia się ono tymczasem zarówno w oporze rządzonych, jak i powściągliwości rządzących. Politycy szczerze przywiązani (wbrew swojemu wąsko pojętemu interesowi) do liberalnych elementów panującej ideologii będą zapewne tworzyć lepsze (choć wedle libertariańskich standardów bezsprzecznie dalekie od doskonałości) prawa i w większym stopniu ich przestrzegać, respektując werdykty sądów konstytucyjnych, stosujących ze swojej strony bardziej przyjazne wolności interpretacje istniejących przepisów. Nawiązując do nośnego sformułowania Jasaya o konstytucji jako pasie cnoty, do którego klucz znajduje się w zasięgu damy, wolno wysunąć tezę, że w interesie przyjaciół cnoty leży przekonanie damy, że gdy tylko zdecyduje się sięgnąć po klucz, sam Bóg porazi ją piorunem.

Krótko mówiąc, można stwierdzić, że jeśli libertarianie życzą sobie, by ich idee były choćby w minimalnym stopniu wcielane w życie, muszą zabiegać o promocję tych składników zastanej kultury politycznej, które im sprzyjają. Nielibertarianie, odrzucając radykalizm formułowanej w szczególności przez Hoppego krytyki demokracji, mogą natomiast dzięki niej nauczyć się podejrzliwości wobec na pozór czysto dobroczynnych instytucji.

\section{Bibliografia}

Antydemokrata - wróg publiczny numer jeden - wywiad z Hansem-Hermannem Hoppe, http:// liberalis.pl/2007/04/01/wywiad-z-hansem-hermannem-hoope/.

${ }^{67}$ H.-H. Hoppe, Krótka historia człowieka..., s. 172.

68 E. de la Boettie, The Politics of Obedience. Discource of Voluntary Servitude, s. 41-49, https:// mises.org/system/tdf/Politics\%20of\%20Obedience.pdf?file=1\&type=document (dostęp: 05.11.2017).

${ }^{69}$ H.-H. Hoppe, Demokracja..., s. 353. 
Antoszewski A., System polityczny RP, Warszawa 2012.

Arendt H., Korzenie totalitaryzmu, przeł. D. Grindberg, M. Szawiel, t. 1, Warszawa 1993.

Bartyzel J., Śmiertelny bóg Demos. Pięć wykładów o demokracji i jej krytykach, Warszawa 2009.

Boettie E. de la, The Politics of Obedience. Discource of Voluntary Servitude, s. 41-49, https://mises.org/system/tdf/Politics\%20of\%20Obedience.pdf?file=1\&type=document.

Brzeziński Z., Friedrich C., Totalitarian Dictatorship and Autocracy, New York 1966.

Cuzan A.G., Some Principles of Politics, „Libertarian Papers” 2017, vol. 2 (9).

Downs A., An Economic Theory of Democracy, New York 1957.

Habermas J., Teoria działania komunikacyjnego, przeł. A.M. Kaniowski, Warszawa 2015.

Hayek F.A. von, Konstytucja wolności, przeł. J. Stawiński, Warszawa 2006.

Heywood A., Ideologie polityczne. Wprowadzenie, przeł. M. Habura et al., Warszawa 2007.

Hoppe H.-H., Demokracja — bóg, który zawiódt. Ekonomia i polityka demokracji, monarchii i ładu naturalnego, przeł. W. Falkowski, J. Jabłecki, Warszawa 2006.

Hoppe H.-H., Ekonomia i etyka własności prywatnej. Studia z zakresu ekonomii politycznej i filozofii, przeł. K. Nowacki, Warszawa 2011.

Hoppe H.-H., F.A. Hayek on Government and Social Evolution. A Critique, „The Review of Austrian Economics" 1994, vol. 1 (7).

Hoppe H.-H., Krótka historia człowieka, przeł. Ł. Dominiak, Warszawa 2014.

Hoppe H.-H., Teoria socjalizmu i kapitalizmu. Ekonomia, polityka i etyka, przeł. P. Nowakowski, Wrocław 2015.

Huemer M., The Problem of Political Authority. An Examination of the Right to Coerse and the Duty to Obey, New York 2013.

Jasay A. de, The State, Indianapolis 1998, http://www.econlib.org/library/LFBooks/Jasay/jsyStt20. html\#4.1 Fixed Constitutions.

Jouvenel B. de, Traktat o władzy, przeł. K. Śledziński, Warszawa 2013.

Juruś D., W poszukiwaniu podstaw libertarianizmu. W perspektywie Rothbardowskiej koncepcji własności, Kraków 2012.

Kinsella S., What libertarianism is, [w:] Property, Freedom, and Society. Essays in Honour of Hans-Hermann Hoppe, red. J.G. Hulsmann, S. Kinsella, Aurburn 2009, s. 179-196.

Kuehnelt-Leddihn E. von, Demokracja — opium dla ludu, przeł. M. Gawlik, Warszawa 2012.

Marcuse H., Człowiek jednowymiarowy: badania nad ideologia rozwiniętego społeczeństwa przemystowego, przeł. S. Konopacki, Warszawa 1991.

Marcuse H., Repressive Tolerance, [w:] idem, R.P. Wolff, B. Moore, A Critique of Pure Tolerance, Boston 1965, s. 81-117.

Monteskiusz, O duchu praw, przeł. T. Boy-Żeleński, Kraków 2016.

Nowakowski P., Dlaczego rządzą źli? O krytyce demokratycznych zarządców w filozofii politycznej Hansa-Hermanna Hoppego, „Dialogi Polityczne” 2010, nr 13.

Rawls J., Liberalizm polityczny, przeł. A. Romaniuk, Warszawa 2012.

Rothbard M.N., Egalitaryzm jako bunt przeciwko ludzkiej naturze, przeł. K. Węgrzecki, Warszawa 2009.

Rothbard M.N., Etyka wolności, przeł. J. Wozinski, Warszawa 2010.

Rothbard M.N., O nowa wolność. Manifest libertariański, przeł. W. Falkowski, Warszawa 2007.

Sartori G., Teoria demokracji, przeł. P. Amsterdamski, D. Grindberg, Warszawa 1998.

Schumpeter J.A., Kapitalizm, socjalizm, demokracja, przeł. M. Rusiński, Warszawa 2009.

Slenzok N., Hansa-Hermanna Hoppego libertariańska rehabilitacja monarchii. Analiza metodologiczna, „Societas et Ius” 2016, nr 5.

Spooner L., Nie-Zdrada, przeł. S. Sękowski, Warszawa 2008.

Talmon J.L., Źródła demokracji totalitarnej, przeł. A. Ehlrich, Kraków 2015.

Teoria wyboru publicznego, red. J. Wilkin, Warszawa 2005.

Studia nad Autorytaryzmem i Totalitaryzmem 40, nr 2, 2018

(C) for this edition by CNS 


\section{TOTALITARIAN DEMOCRACY PROBLEM IN THE POLITICAL PHILOSOPHY OF LIBERTARIANISM}

\section{Summary}

The aim of the paper involves presentation and evaluation of the concept of totalitarian democracy, which is to be found in the works of the libertarian political philosophy proponents: Murray N. Rothbard and Hans-Hermann Hoppe. In the course of our analysis, the author formulates following tenets. Firstly, although libertarian thinkers do not employ the expression „totalitarian democracy" themselves, that notion can be successfully identified in their writings. To Rothbard and Hoppe democracy - including the liberal one - is a totalitarian system by nature. It is supposed to stem from democratic regime's lust for taking control over all aspects of individual's life (in libertarian terms: all aspects of the use of private property), as well as from the inherent fallacies of liberal safeguards, designed in order to protect democracy from degradation to mere tyranny of majority, such as the rule of law, constitutionalism, and checks and balances principles. Secondly, in author's judgement, however Rothbard's and - in particular - Hoppe's critique of democracy should be considered consistent with libertarian ideals, it appears to a certain extent exaggerated also in their light.

Keywords: libertarianism, democracy, totalitarianism, political philosophy, politcal theory.

Norbert Slenzok

n.slenzok@onet.eu 